\title{
ПСИХОЛОГІЧНІ АСПЕКТИ САМОСТВЕРДЖЕННЯ ДІТЕЙ ДОШКІЛЬНОГО ВІКУ ЗАСОБАМИ РУХОВОЇ ДІЯЛЬНОСТІ
}

\author{
Оксана Жизномірська \\ кандидат психологічних наук, доцент, доцент кафедри \\ педагогіки і психології та інклюзивної освіти \\ Тернопільський обласний комунальний інститут післядипломної педагогічної освіти \\ 46027, Україна, м. Тернопіль, вул. Громницького, 1 \\ o.ya.oksana@ukr.net, http:/orcid.org/0000-0002-0453-2800
}

\begin{abstract}
Анотація
У статті окреслено психологічні виміри самоствердження дитини дошкільного віку; визначено різні способи рухової діяльності дитини, що забезпечує іiі повноцінний та гармонійний розвиток; зроблено акцент на позитивному сприйнятті себе в певних соціальних дитячих ситуаціях, зокрема, самоствердження за допомогою моторних дій, активностей, дитячих випробувань; здійснено ретельний аналіз спектру рухової діяльності дитини-дошкільника та iï вплив на самопочуття та здоров'я; здійснено бліц-опитування для вихователів (мінідослідження); запропоновано перелік творчих зустрічей із батьками, вихователями щодо підвищення рухової компетентності та життєствердження дошкільників. Мета: статтю присвячено вивченню психологічного аспекту життєствердження за допомогою використання рухових дій дошкільниками; особливостей формування рухових навичок та набуття рухового досвіду дітьми; конструктивного налагодження комунікації дорослого з дітьми дошкільного віку засобами фізкультурно-оздоровчого спрямування. Методи дослідження: теоретичні (аналіз, синтез, порівняння, моделювання); емпіричні (спостереження, бесіда, інтерв'ю, вивчення продуктів діяльності). Результати. В онлайн міні-дослідженні (бліц-опитування) взяло участь 600 педагогічних працівників сфери дошкільної освіти Тернопільської області, де було встановлено, що лише $43 \%$ респондентів мають сумніви щодо професійної компетентності в руховій діяльності, оскільки остання вимагає надмірних зусиль, активностей, моторних прагнень; 34\% респондентів вважають за необхідне бути міцними, стрункими, активними вихователями та демонструвати свої досягнення перед дітьми; 19\% не змогли визначитися однозначно й 4\% респондентів дали негативну відповідь. Висновки. За результатами проведеного бліц-опитування (онлайн) для вихователів закладів дошкільної освіти було визначено, що діти-дошкільники постійно себе презентують у різних рухах, активностях, сміливо та впевнено демонструють власне «Я» (швидкість, спритність, витривалість рухів, дій), вірніше «шукають» себе в цій діяльності, однак прагнення дітей мають співпадати з бажаннями вихователя задля поставленої мети власної «рухової» реалізації.
\end{abstract}

Ключові слова: самоствердження, саморозуміння, самоставлення, цінності, ціннісні орієнтації дітей дошкільного віку, рухова активність, діяльність, світогляд, моральні принципи.

\section{Вступ}

У реаліях сьогодення перед дошкільною освітою постають пріоритетні завдання підготовки молодого покоління до особистісних успіхів, саморозкриття в дитячому 
середовищі, почуттів власної гідності в різних соціальних спільнотах. Як бачимо, на сьогодні спостерігається доволі складна та напружена ситуація щодо позитивного самоствердження «Я» дошкільника. Особливо важливого значення набувають не лише питання, пов'язані 3 вихованням, навчанням, особливостями розвитку дошкільників, а й з вмінням дорослого швидко та влучно реагувати на їх виклики, запити, запитання, оскільки останні засвідчують нам про пізнавальну активність, допитливість, кмітливість, творчу ініціативність, позитивну емоційність, що мають стійке прагнення до особистісного презентування себе в колі значущих осіб. Тому, сучасні батьки або інші дорослі, які опікуються дошкільниками, з одного боку, намагаються здійснювати позитивні, переконливі виховні впливи на дитину, застосовуючи при цьому різні стилі спілкування та управління; демонструють поведінку певного ракурсу; стійко наполягають на власних принципах, правилах співпраці з різними особистостями; а, 3 іншого - їх наміри можуть відрізнятися від позицій інших осіб (вихователі, музичні керівники, фізичні інструктори, завідувачі) та характеризуватися підвищеним рівнем конфліктності, упередженого ставлення, амбіційності, примхливості, критичності. Реалізація вище окресленого безпосередньо пов'язана із завданнями дошкільної педагогіки та психології, й покликана якісно надавати освітні послуги, професійно відповідати на різномодальні виклики, очікування дошкільників та їхніх батьків.

Переконані, що дитина, перебуваючи на етапі дошкільного дитинства, в процесі конструктивного спілкування та особистісного становлення, якомога швидше, сьогодні, починає усвідомлювати власне «Я», проявляти самостійність, життєздатність у власних рішеннях, здійснювати моральний вибір та, водночас, може навіть пропонувати певні альтернативи для дорослих (батьків, опікунів, вихователів).

Діти цифрового бачення, мислення, сприйняття, які вони насправді - ці та інші питання хвилюють багатьох фахівців дошкільної сфери та сучасних батьків і, зрештою, спонукають нас до вмінь «вибудовувати» діалогічне спілкування 3 ними, позитивного мислення, домовлятися з ними у форс-мажорних ситуаціях, відстоювати власну гідність як пріоритетну цінність дитини, презентувати себе в різних іпостасях (ролях), медіаграмотності, рухової компетентності. Власне кажучи, діти дошкільного віку мають можливість проявляти самодостатність у мікрогрупі та самостверджуватися перед своїми однолітками, педагогами та батьками. Ті труднощі, з якими ми (дорослі) зіштовхуємося, додають нам сили, міцності, мужності, завзятості, натхнення долати життєві й професійні негаразди та цілісно окреслювати свій алгоритм (траєкторію) дій i практичного застосунку в тандемі із «пізнайками»-дошкільниками.

У Базовому компоненті дошкільної освіти (Державний стандарт дошкільної освіти) у новій редакції визначено такі освітні напрями як «Особистість дитини», «Дитина в сенсорнопізнавальному просторі», «Дитина в грі», «Дитина в соціумі», «Дитина в світі мистецтва» та ін., що засвідчує про повноцінний розвиток та їі позитивне самоствердження. В основу цього документа також покладено наступні цінності дошкільної освіти: визнання самоцінності дошкільного дитинства, його потенціалу; щасливе дитинство; повага до дитини, до особливостей їі розвитку; цінність життя та благополуччя як вміння плекати, підтримувати та створювати сприятливі умови для себе та інших у безпечному середовищі; розвиток творчих задатків, здібностей, талантів дитини; збереження традицій, сімейного досвіду та суспільного виховання задля збагачення культурного потенціалу взаємодії між різними поколіннями (Базовий компонент, 2021). 
На нашу думку, в умовах глобалізації та освітніх змін, особистість дошкільного віку «змальовує» власний проект життєздатності та самореалізації, що спочатку здійснюється під керівництвом значущих дорослих (батьки), а, зрештою, - супроводжується інноваційним мисленням власного «Я» та «Я»-іншого в соціальному просторі. Розуміємо, що діти дошкільного віку намагаються виокремитися 3-поміж інших та швидко привернути увагу до себе власними бажаннями, потребами, мріями, фантазіями, рухливими діями, вірніше самоствердитися за допомогою ігор тощо.

Актуальності набуває вивчення процесу самоствердження особистості в період дошкільного дитинства, коли з'являється багато прагнень до пізнання власного «Я», своєї «самості», загострюється необхідність перебувати в оточенні однолітків, частіше виявляється орієнтація на особистісні позиції «Я - знаю, пізнаю, вмію, дію, роблю, думаю, хочу, мрію», зростають очікування та сподівання на оточуючий світ. Ми звертаємо увагу на період раннього віку, котрий є визначальним для подальшого повноцінного та гармонійного розвитку дошкільників. Зокрема, такі вчені, як К. Блага, М. Лісіна, В. Мухіна, М. Шебек зазначали про «закладення підвалин» самосвідомості дитини для повноцінного розгортання себе в соціумі. Насамперед, К. Блага і М. Шебек акцентували увагу на розвитку «структурного та глобального «Я»» дитини раннього віку (Блага \& Шебек, 1991); М. Лісіна розглядала генезу самоствердження дитини, що здійснюється завдяки кооперації із батьками (сімейний тандем самоствердження) (Лісіна, 1986); В. Мухіна трактувала процес самоствердження шляхом формування (зародження) мовної, поведінкової та моральної компетентностей (Мухіна, 2000); вітчизняна дослідниця О. Кононко деталізувала процес саморегуляції та формування моральних якостей особистості на цьому етапі дошкільного дитинства (Кононко, 1998).

Деякі питання щодо процесів самоствердження, саморозуміння, саморозкриття окреслювали вчені та наполягали на власних наукових баченнях Зокрема, дослідниця Л. Божович вікову кризу дошкільного віку пов'язувала 3 процесом самоусвідомлення та самоствердження (Божович, 1995); О. Кононко доводила, що утвердження власного «Я» дошкільника серед інших відбувається завдяки засвоєнню соціального досвіду (Кононко, 1998); В. Котирло та О. Кульчицька вказували, що шлях становлення особистості дитинидошкільника «проходить» через утвердження в емоційно-вольовій сфері, а життєствердні зміни дошкільників «переломлюються» крізь призму узгодженості зовнішніх дій із моральними принципами дитини (Котирло \& Кульчицька, 1963).

Як підкреслювали сучасні дослідники (Агіляр Туклер, 2020; Карасьова, 2010; Карнаух, 2010; Коток, 2019; Ладивір, 2010; Литвишко, 2019; Михальська, 2020; Піроженко, 2011, 2020; Пуйо, 2021; Рейпольська, 2021 та ін.), що життєдіяльність дитини дошкільного віку та їі прояви власного «Я» здійснюються завдяки цілісному поєднанню емоційних, поведінкових та особистісних надбань. Насамперед, у працях вище окреслених учених, основний акцент зроблено на особистісно-орієнтованій педагогічний технології, що характеризується антропоцентричною, гуманістичною та психотерапевтичною спрямованістю, й, власне кажучи, має на меті різнобічний, творчий, незалежний, вільний розвиток особистості дитини дошкільного віку; на формуванні особистісної ідентичності, ціннісного саморозуміння й самоставлення; виробленні безпечної поведінки та комунікативно-мовленнєвої культури дошкільника; на формуванні базових цінностей та здійсненні адекватних (правомірних) виховних впливів на дошкільника засобами ігрових технік та рухової діяльності; на значущості ціннісного «Я» дитини-дошкільника в сучасному соціопросторі; формуванні ціннісних орієнтацій засобами рухливих ігор. 
Мета дослідження полягала у вивченні самоствердження дітей дошкільного віку за допомогою використання різномодальних рухових технік. Завдання дослідження: 1) окреслити ціннісні аспекти життєствердження дошкільників та проаналізувати спектр їх рухової діяльності; 2) ретельно здійснити аналіз щодо проведеного бліц-опитування для вихователів; 3) запропонувати авторські розробки творчих (тематичних планів) зустрічей 3 батьками для фахівців дошкільної сфери.

\section{Методи дослідження}

Основним методом нашого дослідження було бліц-опитування (онлайн) вихователів закладів дошкільної освіти. Опитування містило наступні запитання:

1. Коли (часовий вимір) дитина дошкільного віку краще сприймає заняття з рухової діяльності?

2. Що є найцікавішим із рухових вправ для дошкільників?

3. Що є найскладнішим із рухових ігор у виконанні із дітьми?

4. Що для Вас означає «рухова активність» дитини дошкільного віку?

5. Де Ви найчастіше використовуєте рухливі техніки спільно із дітьми?

6. Чи вважаєте Ви, що застосування якомога більше рухових ігор із дітьми допомагає Вам удосконалюватися у своїй сфері?

В опитуванні взяло участь 600 педагогів-вихователів. Відповідно до отриманих результатів було з'ясовано наскільки вони компетентні із питань рухової діяльності дітей, а також чи вміють працювати 3 дітьми із «руховими викликами». Відповідно до отриманих результатів нами були сформульовано низку незавершених тверджень (авторська розробка), виконання яких налаштовуватиме вихователів дошкільних закладів на професійний саморозвиток та самовдосконалення, зокрема, в напрямку сприяння розвитку рухової активності та діяльності вихованців. Також нами була запропонована тематика батьківських зборів, в яких висвітлювалися питання, пов'язані з особливостями формування та розвитку особистості дошкільника (гендерні особливості, бажання, мрії, креативність тощо), а також пропонувались методи стимулювання гармонійного розвитку емоційно-вольової та конативної сфери дитини-дошкільника.

\section{Результати та дискусії}

Процес самоствердження дитини дошкільного віку здійснюється різними засобами сучасних технологій (гаджетів, комп'ютерів, ноутбуків, планшетів); за допомогою особистісних рухових прагнень (ігри - рухливі, драматизації, сюжетно-рольові, абстрактні, уявні, гімнастика); за допомогою проведення фізкультурно-оздоровчих заходів (розваги, вікторини, конкурси, піші походи, прогулянки). Виходячи з такої позиції, важливо дати зрозуміти вихованцям дошкільного віку процес власного (позитивного) представлення та реалізації себе в дошкільному закладі освіти; самоусвідомлення своїх кращих (сильних) сторін характеру, волі, самостійності, незалежності; формування особистісних принципів, бажань, мрій, вподобань, відчуття власної гідності та ініціативності. Слід зауважити, що маленькі діти (дошкільники) в спілкуванні 3 батьками розпочинають свій день із мобільного телефону/ноутбука, оскільки ігровий контент, який пропонується для дітей певного віку, для них є більш прийнятним, захоплюючим, сенсаційним, мотиваційним, цікавим, аніж ігрова діяльність (реальна). На нашу думку, ми маємо підростаюче молоде покоління (гаджетоване), яке характеризується своєю гнучкістю, швидкістю, динамічністю, багатофункціональністю, 
креативністю та певною незрозумілістю для нас. Однак інноваційне, нешаблонне мислення, ретельний аналіз конкретного кейсу та його вирішення розкриває потенціали та всі шанси до нових відкриттів, проєктів, експериментів, фестивалів на регіональному рівні. Варто також наголосити й на тому, що значущі дорослі (батьки, педагоги) неодмінно мають дбати про розвиток та здоров'я дитини дошкільного віку та постійно супроводжувати іiї у різних дитячих спільнотах, де переважають різновекторні думки та наміри. 3 наших міркувань, батьки разом із вихователями дошкільного закладу можуть ініціювати питання здорового способу життя та різні активності (пожвавлення) дитини, закритий та відкритий простір задля запобігання дитячих хвороб, гіподинамії, а також турбуватися про формування у неї рухових навичок. Насамперед, діти-дошкільники у грі добре тренують свої фізичні якості (швидкість, спритність, витривалість, координація рухів), які $є$ значущими для подальшого їх становлення та розвитку в майбутньому. Так, педагоги дошкільної галузі в тандемі із медиками мають можливість розробляти та спроможні вчасно запропонувати для батьків навчально-методичні настанови, практичні рекомендації щодо зміцнення дитячого здоров'я, психологічного благополуччя завдяки набуттю ними досвіду «руху» в навчальному закладі чи в домашніх умовах. Розуміємо, що сучасні батьки цікавляться новими методиками, способами моторної діяльності, гімнастикою для тіла, фізичними вправами для м'язів тощо, відвідують фітнес центри, центри здоров’я, i, водночас, підтримують своїх дітей у різних починаннях, зокрема, у формування рухової компетентності.

Науковці (Пуйо, 2021; Михальська, 2020) підкреслюють, що доволі цікаво спостерігати за малюками, котрі намагаються яскраво самоствердитися, продемонструвати себе в групі (на занятті, спортивному, актовому залах за допомогою своїх енергійних рухів, танцю, музики, позитивних емоцій); бурхливо проявити себе у поведінці; є непередбачуваними та веселими в різних ситуаціях; ініціативними в своїх ролях та кумедними в думках (Божович,1995; Кононко, 1998). Сучасні дослідники (Піроженко, 2012; Вовчик-Блакитна, 2012) окреслювали, що саме віртуальний простір починає переважати та, все дужче, приваблювати зовнішній світ дошкільника, що виступає в ролі конструктора, який «жорстко» програмує спосіб життя, мораль, визначає сучасну систему цінностей дитини. Так, у дошкільному віці ставлення до світу існує в розгорнутому вигляді, у формі активних дій, проявів, висловлювань, емоцій, тобто картинка світу є відкритою для участі та співучасті з дорослими (Піроженко, 2012: 29). Світоглядна реальність дошкільника лише починає набирати сутнісних обертів, вірніше можливості прояву й самореалізації свого буття в найвищих ідеалах людини - ідеях Істини, Добра й Краси (Піроженко, 2012: 34). Учені робили такі припущення, що процес становлення внутрішньої картинки світу дошкільника $є$ невичерпною можливістю щодо формування уявлень дитини про світ, яке базується на особистому досвіді активного спілкування й взаємодії зі світом людей та природи. Саме когнітивний зміст створення картини світу - це інформація про спосіб пізнання дітьми оточуючого світу. Співавтори монографії зазначають, що кожна дитина дошкільного віку вибудовує, конструює власну картину, «образ» світу, що здійснюється завдяки адекватному спілкуванню 3 дорослими, що має відображення в мозковому субстраті цілеспрямованості дій та якісно збагачує діяльність дитини (Піроженко, Вовчик-Блакитна \& Ладивір, 2012). Ми вважаємо, що кожна дитина намагається відчути власну гармонійність, узгодженість, збалансованість своїх дій та поведінкових прагнень, що корелюється із внутрішнім баченням себе у вимірі реальних подій.

Звертаємо увагу й на мовленнєві досягнення дитини-дошкільника, як відображення досвіду міжособистісних взаємин, що віддзеркалюють такі особистісно значущі психологічні 
феномени як статус дитини в сім'ї та групі дітей, ставлення оточуючих до дитини, які мають право в її оцінці. Особистість - це системоутворення, що має визначений статус у системі соціальних відносин, i, власне ставлення до соціальних відносин, ставлення до самого себе, самоставлення. Цей психологічний феномен включає самосвідомість, самопізнання, самооцінку, емоційне реагування, самоконтроль, й тому самоставлення цілісно характеризує особливості усіх форм активності дитини в різних видах діяльності (Піроженко, 2012: 58).

3 огляду ретельного аналізу змістового наповнення Базового компонента дошкільної освіти, рухова компетентність дошкільника входить до одного із освітніх напрямів, а саме, «Особистість дитини», де передбачено сформованість знань, навичок та емоційно-ціннісного ставлення до себе та інших. Так, рухова компетентність - це здатність дитини до самостійного застосування життєво необхідних рухових умінь та навичок, фізичних якостей, рухового досвіду в різних життєвих ситуаціях (Базовий компонент, 2021). Отже, значущі дорослі (вихователі, батьки) повинні дбати про достатній рівень рухової активності дошкільника, де засвоєння та швидке оволодіння ним уміннями та навичками засвідчуватиме про сформовану компетентність діяти по-різному в соціокультурних реаліях. У цьому документі також зазначено про спектр різноманітних знань, якими має володіти дитина дошкільного віку, а саме добре знати перелік основних рухів, предметів та спортивних знарядь; цілісно усвідомлювати ряд фізичних вправ для зміцнення всього організму; вміти дотримуватися правил у різних іграх; стежити за власною гігієною тощо. Водночас, спектр навичок дошкільника презентовано наступними лініями: сформованість життєво необхідних рухових умінь; розвиненість фізичних якостей; достатній руховий досвід; добре володіння власним тілом; свідома реакція на елементарні потреби організму; стійка витримка до певного фізичного навантаження; прояв вольових зусиль; координація рухів; уміле орієнтування в просторі; здатність самостійно застосовувати руховий досвід у повсякденному житті; правильне оцінювання себе та регуляція своїх можливостей щодо власного тіла; володіння основними рухами (ходьба, біг, стрибки, лазіння, метання); прагнення контролювати власну поставу; усвідомлення свого впливу на здоров'я; естетика рухів тощо. Власне кажучи, дошкільний вік дитини багатий та насичений різними емоціями, що визначають ціннісне ставлення до власного «Я» та «Я»-іншого. Емоційно-ціннісне ставлення вихованцядошкільника віддзеркалюється в наступних дитячих позиціях: виявлення інтересу та потреби у фізичному вдосконаленні; емоційне реагування на власні досягнення в руховій сфері (пластичність, упевненість, виразність, естетика рухів); презентування стійкої позитивної мотивації до активної рухової діяльності; цінування чесності, справедливості, дружелюбності; підтримка в командних спортивних іграх; прояв спритності, жвавості, завзятості; вміння боротися за перемогу та гідно програвати, отримувати невдачу.

У педагогічному контексті рухова активність корелюється із дефініціями самопізнання, саморозкриття, самоставлення, самооцінювання, самореалізації та самоствердження дитини дошкільного віку. Згідно реалій сьогодення, саме останнє питання додає нам упевненості щодо того, що дошкільна освіта потребує змін, інноваційного підходу до розуміння сутності «Я» дитини в соціальному просторі, правильної «перебудови» в спілкуванні дорослого 3 нею, адекватного прийняття іiі можливостей, здібностей, вподобань, позитивного бачення іiі успіхів, дитячих звершень, позитивного утвердження за допомогою власного «Я» (руховий досвід).

Сучасна дослідниця О. Пуйо в дисертаційному дослідженні визначила сутність та структуру ціннісних орієнтацій дітей старшого дошкільного віку, що містить емоційноціннісний, когнітивний та діяльнісний компоненти, а також довела вплив рухливих ігор на 
формування цінностей (співпереживання, дружби) (Пуйо, 2021: 29). Авторка зазначає, що використання сучасних рухливих ігор, таких як «Підіпри вежу», «Перенеси через місточок», «Весела гусінь», «Переправа», «Ринва», «Звивиста доріжка» та ін., а також різні емоційні дидактичні ігри, такі як «Відгадай емоцію», «Дзеркало емоцій», «Подаруй емоцію», «Абетка емоцій», «Кімната сміху», відображають позитивну картинку «Я» цінностей дошкільника. Отже, ціннісні орієнтації - це елементи внутрішньої структури особистості, що визначають вектор іiі діяльності та активність, відповідають за моральний вибір на кожному етапі зростання особистості й визначаються культурними стандартами суспільства, в якому проживає особистість (Пуйо, 2021: 49). Функціонування цінності в житті дитини залежить від: рівнів розвитку структурних компонентів; умотивованості дитини щодо діяльності, в яку включена дитина; наявності психолого-педагогічної підтримки соціально-значущих дій, способів прояву активності дитини в різних видах діяльності; розвитку механізмів вольової регуляції поведінки (контроль, самоконтроль) (Пуйо, 2021: 58). Ми вважаємо, що дитина дошкільного віку може себе проявляти у поведінці, діях, активностях, рухах (конативна сфера), вірніше здатна самостверджуватися через правильно сформовану ціннісну сферу та гідно оцінювати власні та «чужі» досягнення. Дослідниця зауважує про цінності, а саме переживання, творення, подолання обмежень, спілкування, що пов'язані із самосвідомістю та власним трактуванням й самореалізацією.

Сучасна вчена також виокремлювала спортивні, народні, музичні рухливі ігри, до яких вдаються дошкільники та, водночас, у них формуються ігрова мотивація; прагнення до самостійності, відповідальності; вміння презентувати власні почуття, емоції; швидке бачення проблемних ситуацій; позитивної комунікації; величезне бажання бути першою та успішною дитиною. Наголос був також здійснений нею й на створенні педагогічних умов, зокрема, готовності майбутніх практикуючих вихователів до формування ціннісних орієнтацій у дітей старшого дошкільного віку засобами рухливих ігор (співпраця з батьками); системна робота 3 дітьми щодо розвитку їх емоційної чутливості, емпатії; надання дітям більше свободи прояву ініціативи під час рухливих ігор і реалізація набутих знань у міжособистісні взаємини (Пуйо, 2021: 150).

Так, із вихователями закладів дошкільної освіти Тернопільської області нами було проведено бліц-опитування (онлайн) з метою дослідження навичок рухової діяльності дітей дошкільного віку. У цьому опитуванні було з'ясовано їх компетентність із питань рухової діяльності, а також чи вміють вони працювати з дітьми із «руховими викликами».

На запитання «Коли (часовий вимір) дитина дошкільного віку краще сприймає заняття 3 рухової діяльності?», відповіді респондентів були наступні: зранку (25\%), в обідню пору (60\%), ввечері (15\%). Це засвідчує, що дошкільники (60\%) саме набувають своєї активності, жвавості, енергійності в полудень й швидко реагують на будь-які руханки, запропоновані вихователем. Проаналізувавши відповіді на запитання про те, які 3 рухових вправ $\epsilon$ найцікавішим для дошкільників, ми отримали наступні результати: $45 \%$ вихователів зазначають, що дітям подобаються музично-рухливі техніки; 32\% - вказують на переважання святково-розважальних технік; і лише 23\% вихователів відмічають зацікавленість вихованців у спортивних іграх. Саме дітям цього віку найбільш до вподоби руханки із музичним супроводом, оскільки вони себе почувають ніби «співаками», «танцівниками» на сцені, зокрема, їх схвалюють, їм аплодують, вони утверджуються за допомогою власних можливостей, вмінь, міні-досягнень у групі однолітків. 
На запитання, що є найскладнішим із рухових ігор у виконанні із дітьми, нами було отримана такі дані: 41\% - гімнастика, 31\% - конкурси, 28\% - піші переходи. Це дозволяє стверджувати, що гімнастичні рухи є доволі складними у виконанні дітей та потребують більшої наполегливості, цілеспрямованості, зосередженості, аніж інші види (форми) рухових технік. На запитання «Що для Вас означає «рухова активність» дитини дошкільного віку?», 48\% респондентів відповіли - здоров'я дитини, 28\% - відпочинок для тіла, 24\% - зміцнення дитячого імунітету. Зважаючи на такі кількісні показники, можна вважати, що коли дитина дошкільного віку в супроводі з дорослим (вихователі, батьки, старші брати, сестри) тривалий час займається фізкультурою, вдається до рухової діяльності, то в неї формується досвід «руху», який визначає їі як здорову, стійку, життєздатну особистість.

На запитання «Де (територіально) найчастіше вихователь використовує рухливі техніки спільно із дітьми?» ми отримали такі результати: 61\% вихователів надають перевагу фізкультурно-оздоровчим іграм на свіжому повітрі, 33\% - звертаються до рухових вправ у закритому просторі (групі) й лише 6\% респондентів враховують побажання дітей і вносять свої корективи до заняття. Це дозволяє нам стверджувати, що виконання різних рухових технік залежить від пори року, світлової доби, температури повітря, погоди, інших значущих показників, які мають позитивно, корисно впливати на організм дитини, іiі самопочуття, настрій, а не навпаки. Окрім цього, вихователі мають бути також зацікавлені, добре вмотивовані до своєї діяльності, внутрішньо відчувати дітей, їм допомагати реалізовуватися у різних дитячих спільнотах, вірніше життєстверджуватися позитивно перед значущими дорослими.

Відповіді, отримані на запитання про те, чи вважає вихователь, що застосування ним якомога більше рухових ігор із дітьми сприяє йому удосконалюватися у своїй сфері, дали можливість визначити, що лише $34 \%$ вихователів однозначно погодилися, оскільки особистість фахівця професійно зростає, вдосконалює свої практичні вміння, навички щодо підвищення моторної активності, а також з упевненістю використовує певні пожвавлення на занятті. Натомість 43\% респондентів зазначали, що рухову компетентність у дошкільників, все ж таки, можна сформувати, проте їхня професійна майстерність у роботі залежить від особистісних прагнень, бажань, мотивів працювати на вдосконалення. В свою чергу $19 \%$ досліджуваних не змогли визначитися із відповіддю й окреслили - «важко сказати», лише 4\% - продемонстрували негативний відгук. Це засвідчує про низький рівень компетентності вихователів щодо власної реалізації та вмінь співпрацювати з дітьми, які щоразу набувають міні-досвіду та, водночас, орієнтуються на думку, емоцію, поведінку, рух дорослого (вихователя, помічника). Ми переконані в тому, що педагоги мають уміти позитивно презентувати власне «Я» в будь-яких соціальних ситуаціях й навіть, форс-мажорних, оскільки «картинка - Я» дитини набуває чинності на цьому віковому етапі.

На нашу думку, особистість дошкільного віку має можливості гідно та активно розвиватися, правильно діяти, спілкуватися із однолітками, вихователями та батьками. Ми пропонуємо низку незавершених тверджень для власного самовдосконалення й самозростання вихователів (авторська розробка):

- Найбільше я ціную в своєму житті........

- Мені імпонує на роботі......

- У спілкуванні із дошкільниками, я надаю перевагу (ігрові технології)...

- Я сприймаю батьків як.....

- Мені найскладніше працювати з дітьми-дошкільниками тоді, коли.....

- Я постійно відчуваю себе.... 
- Я прагну.....

- Мені здається....

- Я вмію добре....

- Мені іноді так хочеться.....

Тематика батьківських зборів (цікавих зустрічей):

1. Вікові, індивідуальні та гендерні особливості дітей дошкільного віку.

2. Потреби, прагнення, бажання, наміри дітей.

3. Мрії, фантазії, ігри, творчі уявлення.

4. Виклики, запити, очікування дошкільників та їхніх батьків.

5. Цифрове навчання, виховання сучасних дошкільників.

6. Гіперактивність, дитиноцентризм, багатовекторність ідей дітей.

7. Креативність дітей, технологічність.

8. Робототехніка. Космос.

9. Стилі спілкування та виховання.

10. Поведінка. Дисципліна. Свобода волі.

11. Цінності. Бачення. Почуття власного «Я». Гідність дошкільника.

12. Формування патріотичних почуттів та національної ідентичності.

13. Форми самоствердження, саморозкриття, становлення дітей-дошкільників.

14. Правила/принципи співпраці з іншими значущими дорослими та однолітками.

15. Безконфліктне спілкування батьків, вихователів, музичного керівника із дітьми дошкільного віку.

Підсумовуючи, можна сказати, що вихователі мають широке, «багатогранне поле» для творчої самодіяльності та цілковитої реалізації дошкільників на різних заняттях, застосовуючи інтерактивні, рухові технології, а також вони разом (дитина та дорослий) крокують до незвичайної «сторінки» власних уподобань, мрій, можливостей та життєствердження в соціумі.

\section{Висновки}

За результатами проведеного дослідження (онлайн бліц-опитування із вихователями дошкільних закладів), яке проводилося на базі Тернопільського обласного комунального інституту післядипломної педагогічної освіти було встановлено, що менше половини (43\%) респондентів мають сумніви щодо професійної компетентності, а саме в руховій діяльності, оскільки остання вимагає надмірних зусиль, активностей, моторних прагнень, натомість третина респондентів (34\%) вважають за необхідне бути міцними, стрункими, дієвими вихователями та демонструвати свої досягнення перед дітьми; 19\% - не змогли однозначно визначитися із відповіддю і лише 4\% - дали негативну відповідь. Саме вихователі наполягали на тому, що виклики «руху» дошкільників $є$ для них трішки проблемними, оскільки потребують значних зусиль, практичних умінь, професійних компетенцій, бажань, енергійності швидко реагувати на запити та професійно подавати приклад для наслідування. Отже, ми вважаємо, що педагогам необхідно розпочинати із власної програми самозростання та спільної програми щодо підвищення професійних компетентностей у руховій діяльності.

Перспективи подальших досліджень полягають у розробці власної моделі саморозкриття дитини дошкільного віку засобами здоров'язбережувальних технологій. 


\section{Література}

1. Агіляр Туклер, В.В. (2016) Ініціативність дитини дошкільного віку як психологопедагогічна проблема сучасності. Матеріали VI щуорічної Всеукраїнської науковопрактичної конференції. "Дослідження молодих учених у контексті розвитку сучасної науки» (Київ 21 квітня 2016). (с. 77-84 ). Київ

2. Агіляр Туклер, В.В. (2020). Виховання ініціативності дітей старшого дошкільного віку в сюжетно-рольовій грі. (Дис. канд. пед. наук). Київ.

3. Бєлєнька, Г.В, \& Пуйо, О.І. (2019). Формування ціннісних орієнтирів дітей дошкільного віку: Сінгапур - Україна, порівняльний аспект. Наукові записки Тернопільського національного педагогічного університету імені В. Гнатюка. Серія: Педагогіка, 2, 6-13.

4. Блага, К., \& Шебек, М. (1991). Я-твой ученик, ты мой учитель. Москва : «Просвещения».

5. Божович, Л.И. (1995). Проблемы формирования личности. Избранные психологические труды. Москва : Международная педагогическая академия

6. Дятленко, Н.М. (2002). Психологічні умови розвитку самоповаги у дошкільників. (Автореф. дис. канд. псих. наук). Київ.

7. Карасьова, К.В., \& Піроженко, Т.О. (2010). Ігровий простір дитини. Київ : «Шкільний світ».

8. Карасьова, К.В, \& Піроженко, Т.О. (2011). Самодіяльні ігри дитини. Київ : «Шкільний світ».

9. Карасьова, К.В. (2014). Розвиток ціннісних орієнтирів старших дошкільників у самодіяльній грi. Режим доступу: http://lib.iitta.gov.ua/6218/1/\%D0\%94\%D0\%BE\%D0\% BA\%D1\%83\%D0\%BC\%D0\%B5\%D0\%BD\%D1\%82_Microsoft_Office_Word.Pdf

10. Карнаух, Л.П. (2010). Виховання безпечної поведінки дітей дошкільного віку в соціальному середовищі. (Дис. канд. пед. наук). Київ

11. Кононко, О.Л. (1998). Соцуіально-емоційний розвиток особистості. Київ : «Освіта».

12. Коток, М.О. (2019). Виховання особистісної ідентичності у дітей старшого дошкільного віку. (Дис. канд. пед. наук). Київ.

13. Котырло, В.К., \& Кульчицкая, О.И. (1963). Воспитание культуры поведения у детей дошкольного возраста. Киев.

14. Лисина, М.И. (1986). Проблемы онтогенеза общения. Москва : «Педагогика».

15. Литвишко, О.М. (2019). Формування основ соціальної компетентності дітей 5-6 років засобами казки в дошкільних навчальних закладах. (Дис. канд. пед.наук). Київ.

16. Михальська, С.А. (2020). Психологія мовленнєвої поведінки дитини 5-7 років життя. (Дис. доктора пс. наук). Київ.

17. Мухина, В.С. (2000). Возрастная психология: феноменологія, развития, детство, отрочество. Москва : «Академия».

18. Наказ МОН України від 12.01.2021p. №33 «Про затвердження Базового компонента дошкільної освіти» (Державного стандарту дошкільної освіти). Нова редакція. Режим доступу: https://mon.gov.ua/storage/app/media/rizne/2021/12.01/Pro_novu_redaktsiyu\%20 Bazovoho\%20komponenta\%20doshkilnoyi\%20osvity.pdf

19. Піроженко, Т.О., Ладивір, С.О., \& Вовчик-Блакитна, О.О. $\quad$ (2012). Становлення внутрішньої картини світу дошкільника. (Монографія). Кіровоград : «Імекс-ЛТД». Режим доступу: http://lib.iitta.gov.ua/1604/

20. Піроженко, Т.О. (2010). Комунікативно-мовленнєвий розвиток дошкільника. Тернопіль : «Мандрівець».

21. Піроженко, Т.О. (2010). Особистість дошкільника: перспективи розвитку. Тернопіль : «Мандрівець».

22. Пуйо, О.I. (2021). Рухливі ігри як засіб формування ціннісних орієнтацій дітей старшого дошкільного віку. (Дис. доктора філософії). Київ.

23. Рейпольська, О.Д. (2021). Теоретико-методичні засади формування у дошкільників ціннісного самоставлення. (Дис. доктора пед. наук). Київ. 
24. Bielenka, H., \& Puyo, O. (2019). Emphathy formation of senior preschoolaged children in the process of active games. Modern world tendencies in thedevelopment of science, 2, 16-25.

25. Bielenka, H. \& Рuуо, О. (2020). Педагогічні умови використання рухливих ігор з метою формування ціннісних орієнтацій дошкільників. Pedagogia. Zeszyty naukowe, 1, 6-10. ISSN 2544-8889

26. Puyo, O. (2020). Active games of preschoolers in the measurement of personal values in Ukraine. Journal of Education. Health and Sport. 10(4). ISSN 2391-8306. Режим доступу: https://apcz.umk.pl/czasopisma/index.php/JEHS/article/view/JEHS.2020.10.04.036

\section{References}

1. Ahiliar Tukler, V.V. (2016). Initsiatyvnist' dytyny doshkilnoho viku yak psykholohopedahohichna problema suchasnosti [The initiative of the child preschool age as a psychological and pedagogical problem of our time]. Materialy VI shchorichnoi Vseukrainskoi naukovopraktychnoi konferentsii «Doslidzhennia molodykh uchenykh u konteksti rozvytku suchasnoi nauky» (21 kvitnia 2016) - Proceedings of the VI Annual All-Ukrainian Scientific and Practical Conference "Research of Young Scientists in the Context of the Development of Modern Science" (April 21, 2016) (pp.77-84). Kyiv [in Ukrainian].

2. Aguilar Tukler, V.V. (2020). Vykhovannia initsiatyvnosti ditei starshoho doshkilnoho viku v siuzhetno-rolovii gri [Education of initiative of children of senior preschool age in a plot-role game]. Candidate's thesis. Kyiv [in Ukrainian].

3. Bielenka, H.V., \& Puyo, O.I. (2019). Formuvannia tsinnisnykh oriientyriv ditei doshkilnoho viku: Sinhapur - Ukraina, porivnialnyi aspekt [Formation of valuesof preschool children: Singapore Ukraine, comparative aspect]. Naukovi zapysky Ternopilskoho natsionalnoho pedahohichnoho universytetu imeni V. Hnatiuka. Seriia: Pedahohika - Scientificnotes of Ternopil National Pedagogical University named after V. Hnatyuk. Series: pedagogy, 2, 6-13. [in Ukrainian].

4. Blaga, K. \& Shebek, M. (1991). Ya-tvoi uchenyk, tu moi uchytel [I am your student, you are my teacher]. Moscow : "Prosveshchenyia" [in Russian].

5. Bozovic, L. (1995). Problemy formyrovanyia lychnosty. Yzbrannye psykholohycheskye trudy [Selected psychological works. Problems of personality formation]. Moscow: Mezhdunarodnaia pedahohycheskaia akademyia [in Russian].

6. Dyatlenko, N. (2002). Psykholohichni umovy rozvytku samopovahy u doshkilnykiv [Psychological conditions for the development of self-esteem inpreschoolers]. Extended abstract of Candidate's thesis. Kyiv [in Ukrainian].

7. Karaseva K.V., \& Pirozhenko T.O. (2010). Ihrovyi prostir dytyny [Child's play space]. Kyiv : "Shkilnyi svit" [in Ukrainian].

8. Karaseva, K.V., \& Pirozhenko, T.O. (2011). Samodiialni ihry dytyny [Amateur child games]. Kyiv : "Shkilnyi svit" [in Ukrainian].

9. Karaseva, K.V. (2014). Rozvytok tsinnisnykh oriientyriv starshykh doshkilnykiv u samodiialnii hri [Development of seniors' valuespres choolers in an amateur game]. Retrieved from http://lib.iitta.gov.ua/6218/1/\%D0\%94\%D0\%BE\%D0\%BA\%D1\%83\%D0\%BC\%D0\%B5\%D0 \%BD\%D1\%82_Microsoft_Office_Word.Pdf [in Ukrainian].

10. Karnaukh, L.P (2010). Vykhovannia bezpechnoi povedinky ditei doshkilnoho viku v sotsialnomu seredovyshchi [Educating safe behavior of preschool children in a social environment]. Candidate's thesis. Kyiv [in Ukrainian].

11. Kononko, O.L. (1998). Sotsialno-emotsiinyi rozvytok osobystosti [Socio-emotional development of personality]. Kyiv : "Osvita" [in Ukrainian].

12. Kotok, M.O. (2019). Vykhovannia osobystisnoi identychnosti u ditei starshoho doshkilnoho viku [Education of personal identity in older preschool children].(Dissertation for Candidate of Pedagogical Sciences). Candidate's thesis. Kyiv [in Ukrainian].

13. Kotyrlo, V.K., \& Kulchitskaya, O.I. (1963). Vospytanye kultury povedenyia u detei doshkolnoho vozrasta [Educating the culture of behavior in preschool children]. Kyiv [in Russian]. 
14. Lisina, M.I. (1986). Problemy ontoheneza obshchenyia [Problems of ontogenesis of communication]. Moscow: "Pedahohyka" [in Russian].

15. Litvishko, O.M. (2019). Formuvannia osnov sotsialnoi kompetentnosti ditei 5-6 rokiv zasobamy kazky $\mathrm{v}$ doshkilnykh navchalnykh zakladakh [Formation of bases of social competence of children of 5-6 years by means of a fairy tale in preschool educational institutions]. Candidate's thesis. Kyiv [in Ukrainian].

16. Mikhalskaya, S.A. (2020). Psykholohiia movlennievoi povedinky dytyny 5-7 rokiv zhyttia [Psychology of speech behavior of a child 5-7 years of age]. Doctor's thesis. Kyiv [in Ukrainian].

17. Mukhina, V.S. (2000). Vozrastnaia psykholohyia: fenomenolohiia, razvytyia, detstvo, otrochestvo [Age psychology: phenomenology, development, childhood, adolescence]. Moscow : "Akademyia" [in Russian].

18. Nakaz MON Ukrainy vid 12.01.2021r. №33 «Pro zatverdzhennia Bazovoho komponenta doshkilnoi osvity (Derzhavnoho standartu doshkilnoi osvity).Nova redaktsiia [Order of the Ministry of Education and Science of Ukraine dated January 12, 2021 №33 "On approval of the basic component of preschool education" (State Standard of Preschool Education). New edition]. Retrieved from https://mon.gov.ua/storage/app/media/rizne/2021/12.01/Pro_novu_reda ktsiyu\%20Bazovoho\%20komponenta\%20doshkilnoyi\%20osvity.pdf [in Ukrainian].

19. Pirozhenko, T.O., Ladyvir, S.O., \& Vovchyk-Blakytna, O.O. (2012). Stanovlennia vnutrishnoi kartyny svitu doshkilnyka [Formation of the inner picture of the world of the preschooler]. Kirovohrad : "Imeks-LTD". Retrieved from http://lib.iitta.gov.ua/1604/_[in Russian].

20. Pirozhenko, T.O. (2010). Komunikatyvno-movlennievyi rozvytok doshkilnyka [Communicative and speech development of a preschooler]. Ternopil : "Mandrivets" [in Ukrainian].

21. Pirozhenko, T.O. (2010). Osobystist doshkilnyka: perspektyvy rozvytku [Preschooler's personality: development prospects]. Ternopil : "Mandrivets" [in Ukrainian].

22. Puyo, O.I. (2021). Rukhlyvi ihry yak zasib formuvannia tsinnisnykh riientatsii ditei starshoho doshkilnoho viku [Moving games as a means of forming the value orientations of older preschool children]. Doctor's thesis. Kyiv [in Ukrainian].

23. Reipolska, O.D. (2021). Teoretyko-metodychni zasady formuvannia u doshkilnykiv tsinnisnoho samostavlennia [Theoretical and methodological principles of forming self-esteem in preschoolers]. Doctor's thesis. Kyiv [in Ukrainian].

24. Bielenka, H.V., \& Puyo, O.I. (2019). Emphathy formation of senior preschoolaged children in the process of active games. Modern world tendencies in thedevelopment of science, 2, 16-25.

25. Bielenka, H. \& Puyo, O.I (2020). Pedahohichni umovy vykorystannia rukhlyvykh ihor z metoiu formuvannia tsinnisnykh oriientatsii doshkilnykiv [Pedagogical conditions for the use of mobile games for the formation of value orientations of the preschoolers]. Pedagogia. Zeszyty naukowe,1, 6-10. ISSN 2544-8889 [in Ukrainian].

26. Puyo, O.I. (2020). Active games of preschoolers in the measurement of personal values in Ukraine. Journal of Education. Health and Sport. 10(4). Poland. ISSN 2391 - 8306. Retrieved from: https://apcz.umk.pl/czasopisma/index.php/JEHS/article/view/JEH S.2020.10.04.036 


\title{
PSYCHOLOGICAL ASPECTS OF PRESCHOOL CHILDREN SELF-ASSESSMENT BY MEANS OF MOTOR ACTIVITY \\ Oksana Zhyznomirska
}

PhD in Psychology, Associate Professor, Associate Professor of the Department of Pedagogy and Psychology and Inclusive Education

Ternopil Regional Municipal Institute of Postgraduate Pedagogical Education

1, Gromnytskoho Str., Ternopil, Ukraine, 46027

o.ya.oksana@ukr.net, http:/orcid.org/0000-0002-0453-2800

\begin{abstract}
The article outlines the psychological dimensions of self-affirmation of the preschool child; identifies different ways of the child's motor activity, which provides full and harmonious development; emphasis is placed on positive self-perception in certain social children's situations - self-affirmation through motor actions, activities, children's challenges; a thorough analysis of the preschool child motor activity spectrum and its impact on well-being and health has been performed; a blitz pool (mini-research) for the educators has been conducted; the list of creative meetings with parents and educators to increase motor competence and life affirmation of preschoolers is offered. The close connection of self-affirmation process with the processes of self-awareness, self-understanding and self-disclosure of the preschool child with the help of own initiative, creativity, children's ideology and thinking is shown. Goal. The article outlines the psychological aspect of self-affirmation by means of the use of motor actions by preschool children; motor experience formation among the children; constructive communication of adults with preschool age children by means of physical culture and health orientation. Research methods: theoretical (analysis, synthesis, comparison, design); empiric (supervision, conversation, interview, activity study). Results. 600 preschool pedagogical staffers from the Ternopil region participated in on-line mine-research (blitz questioning). It is revealed that only $43 \%$ of respondents have doubts in relation to a professional competence in motor activity, as it requires excessive efforts and agile aspirations; $34 \%$ of the teaching staff consider a necessity to be strong, slender and active educators, and demonstrate their achievements to children; $19 \%$ of the respondents are not determined about the answer and $4 \%$ give a negative answer. Conclusions. According to the results of blitz-questioning (on-line) among the educators of preschool establishments, the preschool children constantly present themselves in different motion activities, bravely and confidently expose themselves (speed, adroitness, endurance of motions, actions), to be more exact, "search" themselves in these activities, however, children aspiration must coincide with the educator's desire for the sake of the teacher's aim of "motion" realization.
\end{abstract}

Keywords: self-affirmation, self-understanding, self-attitude, values, value orientations of preschool children, motor activity, activity, worldview, moral principles. 